\title{
GAMBARAN JUMLAH SKS MATA KULIAH PERGURUAN TINGGI FARMASI INDONESIA YANG MENDUKUNG PENGGUNAAN OBAT YANG RASIONAL
}

\author{
VARIATION CUMMULATIVE CREDIT OF INDONESIAN \\ PHARMACY COURSE IN SUPPORTING THE PROMOTION OF \\ RATIONAL DRUG USE
}

\author{
Hendy Ristiono ${ }^{1}$, Sri Suryawati ${ }^{2}$, Sulanto Saleh Danu ${ }^{2}$ \\ ${ }^{I}$ Fakultas Farmasi, Universitas Ahmad Dahlan \\ Jln. Prof. Dr. Soepomo, Janturan, Yogyakarta, Telp. (0274) 379418 \\ ${ }^{2}$ Fakultas Kedokteran, Universitas Gadjah Mada \\ Jl. Farmako Sekip Utara Yogyakarta \\ Email: hendy_ezar@yahoo.com
}

Submitted : 11-09-2015

Reviewed : 14-09-2015

Accepted: 23-11- 2015

\begin{abstract}
ABSTRAK
World Health Organization (WHO) menyebutkan ada dua langkah utama sebagai komitmen untuk melakukan perubahan dalam implementasi praktik farmasi yaitu perubahan kebijakan nasional di bidang obat dan perubahan sistem pembelajaran di Farmasi. Tujuan penelitian ini adalah mengetahui gambaran jumlah sks perguruan tinggi farmasi (PTF) di Indonesia yang mendukung penggunaan obat rasional (POR) berdasarkan Promoting Rational Drug Use (PRDU) International Network Rational Use of Drug (INRUD). Penelitian ini menggunakan rancangan penelitian deskriptif analisis. Lokasi penelitian adalah perguruan tinggi farmasi di Indonesia. Pengumpulan data dilakukan dengan melakukan observasi kurikulum PTF yang terakhir digunakan, pemberian kuesioner tentang topik penggunaan obar rasional dalam kurikulum dan melakukan wawancara mendalam kepada dekan atau staf pengajar yang ditunjuk oleh dekan. Hasil penelitian menunjukkan jumlah sks 21 responden PTF antara 140-158 sks. Median jumlah sks pada 12 perguruan tinggi swasta (PTS) lebih banyak dibandingkan dengan 9 perguruan tinggi negeri (PTN). Median jumlah sks berdasarkan tingkat akreditasi PTF dengan akreditasi C lebih banyak dibandingkan PTF akreditasi A dan B. Dari tiga PTF dengan akreditasi A rentang sks 66-171 sks sedangkan satu PTF dengan akreditasi B sebanyak 36,9 sks sedangkan total sks yang mendukung POR pada minat Farmasi Klinis Komunitas (FKK) lebih banyak dibanding non FKK.
\end{abstract}

Kata kunci : penggunaan obat yang rasional, jumlah sks mata kuliah perguruan tinggi farmasi Indonesia, PRDU INRUD

\section{ABSTRACT}

According to World Health Organization (WHO), there are two major steps as a commitment to make changes in the implementation of pharmacy practice that are national drug policy and learning system changes in pharmacy education. The aim of the research was to obtain the cummulative credit overview in college of pharmacy in Indonesia that supporting Rational Drug Use based on promotion rational drug use (PRDU) and International network rational use of drug (INRUD). This study used a analytic descriptive design. The study was located in some colleges of pharmacy in Indonesia. Data was collected through observation of the recent curriculum used in the Indonesian college of pharmacy. Research were conducted by giving a questionnaire on the rational drug use topic in the curriculum and in-depth interviews with the dean or faculties appointed by the dean. The number of credits developed by 21 colleges of pharmacy as respondents have in between 140-158 credits. Median 
number of credits developed by $\mathrm{C}$ accreditation level are more than $\mathrm{A}$ and $\mathrm{B}$ accreditation level. Three of A accreditation level of colleges have number of credits in between 66-171 credits and a college with B accreditation level as much as 36.9 credits. Whereas in total of credits semester that support the RDU in Community and Clinical Pharmacy (CCP) interests has more than the non-CCP interests.

Keywords: rational drug use, the Indonesian pharmacy college of cummulative credit course, PRDU INRUD

\section{PENDAHULUAN}

Penggunaan obat yang rasional didefinisikan sebagai suatu kondisi jika pasien menerima pengobatan sesuai dengan kebutuhan klinisnya, baik dilihat dari regimen dosis yang sesuai, lama pengobatan yang cukup dan biaya pengobatan yang lebih rendah. Jika pasien menerima pengobatan yang tidak sesuai dengan definisi penggunaan obat yang rasional tersebut maka telah terjadi ketidak rasionalan penggunaan obat atau medication error. WHO juga melaporkan di dunia sekitar $50 \%$ pasien menerima pengobatan yang tidak tepat (WHO, 2002). Data lain di salah satu rumah sakit pemerintah di yogyakarta Indonesia menyebutkan bahwa selama periode bulan juni - september 2007 ditemukan 226 medication error dari 229 resep untuk pasien rawat jalan (Perwitasari dkk, 2010). Penggunaan obat yang tidak rasional dapat menimbulkan dampak morbiditas dan mortalitas yang serius terutama pada pasien anak dengan infeksi dan pasien dengan penyakit kronis (WHO, 2002).

Di era di JKN (Jaminan Kesehatan Nasional) seperti saat ini pelayanan obat merupakan hal yang tidak dapat dipisahkan pelayanan kesehatan. Pelayanan kesehatan di tingkat pertama hingga tingkat rujukan tingkat lanjut meliputi beberapa hal yang salah satunya adalah pelayanan obat dan bahan medis habis pakai (Pemerintah RI, 2013).

World Health Organization (WHO) merumuskan 12 langkah strategi kebijakan untuk menjamin penggunaan obat yang rasional. Salah satunya adalah dengan melaksanakan problembased training farmakoterapi pada kurikulum pendidikan kedokteran dan paramedis. Kualitas pelatihan dasar dalam farmakoterapi pada pendidikan dokter dan paramedis sangat signifikan untuk meningkatkan peresepan yang baik dimasa yang akan datang (WHO, 2012).

The International Network for Rational Use of Drugs (INRUD) pada tahun 2002 telah mengembangkan materi pelatihan penggunaan obat yang rasional yang dikenal dengan Promoting Rational Drugs Use Course (PRDU course) bagi penyedia praktik kesehatan dan merekomendasikan adanya pelatihan bagi mahasiswa kedokteran, farmasi dan paramedis. Berbagai pengembangan telah dilakukan oleh The International Network for Rational Use of Drugs berkaitan dengan promosi penggunaan obat yang rasional, yang akhirnya disepakati ada muatan-muatan yang harus disampaikan tentang penggunaan obat yang rasional di dalam kurikulum perguruan tinggi kesehatan salah satunya adalah perguruan tinggi farmasi yang meliputi pengenalan masalah ketidakrasionalan obat, derajat ketidakrasionalan penggunaan obat, survei dan pengumpulan data, upaya perbaikan penggunaan obat dan tinjauan pedoman pengobatan.

Undang-Undang Kesehatan No.36 tahun 2009 dan Peraturan Pemerintah No.51 tahun 2009 yang mengatur tentang pekerjaan kefarmasian memberikan wewenang yang besar dan strategis kepada tenaga kefarmasian terutama apoteker dalam pelayanan obat kepada pasien. Pelaksanaan promosi penggunaan obat yang rasional dan konseling penggunaan obat pada pasien, apoteker memiliki peranan penting dalam peningkatan kualitas hidup pasien. Begitu penting dan strategisnya peranan Apoteker dalam mendukung pengobatan yang rasional, hingga WHO pada tahun 2002 menyebutkan ada dua langkah utama sebagai komitmen untuk melakukan perubahan dalam implementasi praktik farmasi yaitu perubahan kebijakan nasional di bidang obat dan perubahan sistem pembelajaran di Farmasi.

APTFI (Asosiasi Perguruan Tinggi Farmasi Indonesia) pada tahun 2009 sudah mengeluarkan Kurikulum Nasional Program Pendidikan Sarjana Farmasi. Dalam kurikulum nasional yang jumlah totalnya ada 77 sks tersebut terbagi dalam kelompok mata kuliah pengembangan kepribadian (MPK), kelompok mata kuliah keilmuan dan ketrampilan (MKK), kelompok mata kuliah keahlian 
berkarya (MKB), dan kelompok mata kuliah perilaku berkarya (MPB). Pada tahun 2008 APTFI juga sudah merekomendasikan 16 sks mata kuliah inti program pendidikan profesi apoteker. APTFI selanjutnya meminta kepada perguruan tinggi farmasi untuk mengembangkan kurikulum nasional tersebut sesuai dengan visi dan misi masing-masing.

Kompetensi seorang Apoteker dalam pelayanan obat sangat dipengaruhi dari kurikulum S-1 dan profesi Apoteker yang dikembangkan di perguruan tinggi. Badan akreditasi nasional perguruan tinggi (2012) menyebutkan saat ini terdapat 55 perguruan tinggi farmasi (PTF) sudah terakreditasi di Indonesia, dan 9 PTF lainnya belum terakreditasi. Perguruan Tinggi Farmasi ini dapat dikategorikan berdasarkan status perguruan tinggi negeri (PTN) atau perguruan tinggi swasta (PTS), maupun berdasarkan status akreditasinya, yang memungkinkan terjadinya perbedaan dalam pengembangan kurikulum, belum lagi dalam satu Perguruan Tinggi Farmasi yang memiliki beberapa peminatan atau jurusan, baik yang minat/jurusan farmasi klinis dan komunitas (FKK) maupun minat non farmasi klinis komunitas.

Berdasarkan latar belakang masalah di atas, penulis ingin melakukan kajian tentang gambaran jumlah sks yang dikembangkan Perguruan Tinggi Farmasi didasarkan pada status PTN atau PTS, berdasarkan tingkat akreditasinya, dan berdasarkan pada peminatannya yang mendukung penggunaan obat yang rasional.

\section{METODE PENELITIAN}

Penelitian ini merupakan penelitian non eksperimental dengan rancangan deskriptif analisis. Suatu survei secara nasional yang menggambarkan tentang jumlah sks perguruan tinggi farmasi di Indonesia baik yang berstatus PTN maupun PTS, perguruan tinggi farmasi dengan berbagai tingkat akreditasi, dan juga pada perguruan tinggi farmasi dengan berbagai minat atau penjurusan (BAN PT, 2012). Pengumpulan data dilakukan dengan melakukan observasi terhadap kurikulum terakhir yang digunakan, kuisioner yang dibuat berdasarkan core topic PRDU yang dikirimkan lewat email atau secara langsung, dan melakukan wawancara mendalam kepada dekan atau staf pengajar yang ditunjuk di fakultas/jurusan farmasi di Indonesia yang dilakukan melalui telepon ataupun wawancara langsung untuk PTF yang berada di wilayah Yogyakarta dan sekitarnya.

\section{HASIL DAN PEMBAHASAN}

\section{Karakteristik Responden}

Pada bagian ini akan dibahas mengenai karakteristik responden yang digunakan dalam penelitian. Penelitian ini dilakukan menggunakan 3 metode penelitian yaitu observasi data jumlah sks, kuesioner dan wawancara mendalam. Dari 46 perguruan tinggi farmasi di Indonesia yang dimintai kesediaannya untuk menjadi responden, sebanyak 10 perguruan tinggi farmasi bersedia berpartisipasi untuk menjadi responden dan didapatkan respon sebesar $21,7 \%$.

Sepuluh perguruan tinggi farmasi yang berpartisipasi dalam penelitian, delapan perguruan tinggi farmasi diantaranya memiliki akreditasi A, sehingga data yang didapatkan cenderung menggambarkan kurikulum perguruan tinggi dengan akreditasi A. Dari sepuluh responden perguruan tinggi yang berpartisipasi tersebut, delapan perguruan tinggi diantaranya berstatus sebagai perguruan tinggi farmasi swasta, sehingga data yang diperoleh cenderung lebih menggambarkan kurikulum perguruan tinggi farmasi swasta. Begitu pula jika dilihat dari keberadaan atau domisili sepuluh perguruan tinggi farmasi seluruhnya berada di pulau Jawa, sehingga hasil data yang diperoleh lebih menggambarkan perguruan tinggi farmasi yang berada di pulau Jawa.

Sedikitnya jumlah responden perguruan tinggi yang berpartisipasi dalam penelitian, maka dilakukan observasi jumlah sks di perguruan tinggi farmasi melalui website perguruan tinggi yang tersedia di internet. Hal ini dilakukan untuk mendapatkan informasi tambahan tentang pengembangan kurikulum di masing-masing perguruan tinggi, dan dari hasil observasi didapatkan 21 perguruan tinggi farmasi yang menyediakan informasi jumlah sks pada pendidikan S-1 farmasi, yang terdiri dari sembilan perguruan tinggi farmasi negeri (kode PTN 1-PTN 9) dan dua belas perguruan tinggi farmasi swasta (kode PTS 1- PTS 12). Dua perguruan tinggi farmasi swasta yang menjadi responden tetapi 
tidak terlibat dalam observasi karena informasi kurikulum tidak ditemukan di website selanjutnya akan diberi kode PTS 13 dan PTS 14.

\section{Pengembangan Kurikulum Perguruan Tinggi Farmasi (PTF)}

a. Pengembangan Jumlah sks di Perguruan Tinggi Farmasi

Dari hasil observasi di website perguruan tinggi farmasi yang tersedia di internet tentang jumlah sks dari pengembangan kurikulum yang sedang dilaksanakan dapat dilihat di Tabel I.

Tabel I. Median Jumlah sks S-1 21 Perguruan Tinggi Farmasi

\begin{tabular}{|c|c|c|c|}
\hline No. & $\begin{array}{c}\text { Perguruan Tinggi } \\
\text { Farmasi }\end{array}$ & Akreditasi & Jumlah sks \\
\hline \multicolumn{4}{|l|}{ Negeri } \\
\hline 1. & PTN 1 & A & 144 \\
\hline 2. & PTN 2 & A & 144 \\
\hline 3. & PTN 3 & A & 146 \\
\hline 4. & PTN 4 & A & 154 \\
\hline 5. & PTN 5 & A & 144 \\
\hline 6. & PTN 6 & B & 140 \\
\hline 7. & PTN 7 & B & 147 \\
\hline 8. & PTN 8 & $\mathrm{C}$ & 154 \\
\hline 9. & PTN 9 & $\mathrm{C}$ & 146 \\
\hline \multicolumn{4}{|l|}{ Swasta } \\
\hline 1. & PTS 1 & A & 145 \\
\hline 2. & PTS 2 & $\mathrm{~A}$ & 150 \\
\hline 3. & PTS 3 & A & 144 \\
\hline 4. & PTS 4 & $\mathrm{~A}$ & 146 \\
\hline 5. & PTS 5 & $\mathrm{~B}$ & 146 \\
\hline 6. & PTS 6 & B & 150 \\
\hline 7. & PTS 7 & B & 150 \\
\hline 8. & PTS 8 & B & 140 \\
\hline 9. & PTS 9 & B & 150 \\
\hline 10. & PTS 10 & $\mathrm{C}$ & 158 \\
\hline 11. & PTS 11 & $\mathrm{C}$ & 140 \\
\hline 12. & PTS 12 & $\mathrm{C}$ & 154 \\
\hline \multicolumn{3}{|c|}{ Median jumlah sks PTN (n=9) } & 146 \\
\hline \multicolumn{3}{|c|}{ Median jumlah sks PTS $(n=12)$} & 148 \\
\hline \multicolumn{3}{|c|}{ Median jumlah sks PTF akreditasi A $(n=10)$} & 145 \\
\hline \multicolumn{3}{|c|}{ Median jumlah sks PTF akreditasi B $(n=8)$} & 147 \\
\hline \multicolumn{3}{|c|}{ Median jumlah sks PTF akreditasi $\mathrm{C}(\mathrm{n}=3)$} & 154 \\
\hline
\end{tabular}

Pada Tabel I menunjukkan nilai median jumlah sks kurikulum S-1 yang dikembangkan oleh perguruan tinggi farmasi di Indonesia. Asosiasi Perguruan Tinggi Farmasi Indonesia (APTFI) telah mengeluarkan kurikulum inti untuk pendidikan S-1 farmasi yang berjumlah 77 sks pada tahun 2009, secara umum jumlah sks yang dikembangkan oleh 21 perguruan tinggi farmasi mengalami peningkatan jumlah sks sekitar dua kali lipat dibandingkan kurikulum inti APTFI dengan rentang sks antara 140 - 158 sks. Ini menunjukkan adanya pengembangan muatan lokal yang besar di masingmasing perguruan tinggi farmasi.

Data observasi menunjukkan bahwa 21 perguruan tinggi farmasi dengan klasifikasi status perguruan tinggi, jumlah sks antara perguruan tinggi farmasi negeri dengan perguruan tinggi swasta tidak jauh berbeda. Median jumlah sks pada perguruan tinggi swasta sebanyak 148 sks lebih banyak dibandingkan dengan perguruan tinggi negeri dengan 146 sks, artinya bobot sks baik pada perguruan tinggi negeri ataupun swasta secara umum memiliki bobot yang hampir sama untuk pendidikan S-1 farmasi. 
Data median jumlah sks dengan klasifikasi tingkat akreditasi menunjukkan hasil median jumlah sks yang terbanyak adalah perguruan tinggi farmasi dengan akreditasi C sebesar 154 sks, sedangkan pada perguruan tinggi akreditasi A dan B masing-masing 145 sks dan 147 sks. Fakta ini sangat menarik dan dapat menjadi informasi dan perhatian untuk perguruan tinggi swasta dengan akreditasi $\mathrm{C}$, besarnya beban sks akan menambah beban bagi pelayanan pendidikan maupun beban bagi mahasiswa.

\section{b. Kurikulum Perguruan Tinggi Farmasi yang Mendukung Penggunaan Obat yang Rasional}

Pada bagian ini akan dibahas tentang kurikulum perguruan tinggi farmasi di Indonesia yang mendukung penggunaan obat yang rasional (POR) 12 topik PRDU ini kemudian dikembangkan menjadi kuesioner untuk mendapatkan informasi yang diperlukan, yang kemudian untuk melengkapi tersebut dilakukan wawancara mendalam kepada pimpinan fakultas/prodi farmasi ataupun dosen yang ditunjuk oleh pimpinan fakultas untuk mengisi kuesioner ataupun menjawab pertanyaan yang diajukan saat wawancara. Dalam wawancara mendalam ini melibatkan 10 perguruan tinggi farmasi dan ada 4 perguruan tinggi yang bersedia mengumpulkan kembali kuesioner yang diajukan. Selanjutnya juga akan dibahas perbedaan jumlah sks mata kuliah yang mendukung penggunaan obat yang rasional antara minat farmasi klinis dan komunitas (FKK) dibandingkan dengan minat non farmasi klinis komunitas (non FKK) di satu perguruan tinggi farmasi yang mengumpulkan kembali kuesioner.

Dari jawaban terhadap kuesioner yang diperoleh dari perguruan tinggi swasta, diperoleh data banyaknya sks yang berisi muatan terkait topik-topik yang disarankan oleh INRUD. Data tersebut dilampirkan di Tabel II.

Dari data di Tabel II yang didapatkan dari kurikulum S1 dan profesi, tiga perguruan tinggi dengan akreditasi A secara umum memiliki jumlah sks yang lebih banyak dengan rentang sks 66-171 sks dibandingkan dengan satu perguruan tinggi dengan akreditasi B sebanyak 36,9 sks, hanya pada topik PRDU kesebelas yaitu tentang pedoman pengobatan saja satu perguruan tinggi akreditasi B ini lebih banyak jumlah sks nya dibandingkan dengan yang akreditasi A. Ini dapat disebabkan karena PTS 13 dengan akreditasi B belum memiliki pendidikan profesi apoteker. Hal ini menunjukkan di pendidikan profesi jumlah sks mata kuliah yang mendukung penggunaan obat rasional di tiga perguruan tinggi farmasi akreditasi A cukup besar. Kemungkinan lain yang menjadi faktor kecilnya jumlah sks pada PTS 13 karena pada perguruan tinggi ini menerapkan sistem blok dalam kegiatan belajar mengajar, jadi jumlah sks hanya berupa penggalan-penggalan mata kuliah dalam blok tersebut. Sedangkan jika dilihat dari PTF yang terakreditasi A jumlah sks sangat bervariatif. Hal ini sangat dipengaruhi tujuan atau arah kurikulum masing-masing PTF. PTF-PTF yang jumlah sks muatan POR nya besar kemungkinan arah kurikulumnya memang mengarah pada POR. Sangat disayangkan dalam penelitian ini tidak didapatkan jumlah jam yang diberikan terkait muatan mata kuliah yang mendukung topik PRDU, bisa saja meskipun jumlah sks mata kuliahnya berbeda tetapi memiliki jumlah jam yang tidak berbeda. Disisi lain dari data tersebut jumlah sks mata kuliah di tiga perguruan tinggi farmasi dengan akreditasi A memiliki jumlah sks yang bervariatif terkait topik PRDU.

Dari data Tabel II juga dapat diamati perbedaan jumlah sks antara minat farmasi klinis komunitas (FKK) dengan minat non farmasi klinis komunitas pada PTS 4. Jumlah sks pada minat FKK lebih banyak dibandingkan minat non FKK di sembilan topik PRDU, sedangkan 3 topik lain menunjukkan jumlah sks yang sama. Dilihat dari total sks pada minat FKK hampir dua kali lipat lebih banyak dibandingkan dengan minat non FKK, masing-masing berjumlah 120 sks dan 66 sks. Ini menunjukkan bahwa muatan mata kuliah terkait penggunaan obat rasional pada PTS 4 lebih banyak diajarkan di minat FKK. 
Tabel II. Data Jumlah sks 4 PTS yang Mendukukung Topik PRDU Jumlah sks Perguruan Tinggi Farmasi

Akreditasi A

Akreditasi B

Topik PRDU

PTS 2 PTS 3

PTS 4

PTS 13

Minat Minat non

FKK FKK

Pengenalan mengenai masalah

24

11

5

5

ketidakrasionalan dan bentuk-

bentuk ketidakrasionalan resep

Mengukur derajat

21

8

10

10

1,5

ketidakrasionalan penggunaan

obat di fasilitas kesehatan dan

fasilitas obat

Melakukan survei resep untuk

resep

Pengumpulan data dalam studi ketidakrasionalan

\begin{tabular}{|c|c|c|c|c|c|}
\hline $\begin{array}{l}\text { Kerangka } \\
\text { penggunaan } \\
\text { rasional }\end{array}$ & 25 & 7 & 20 & 8 & 0,7 \\
\hline $\begin{array}{l}\text { Perbaikan penggunaan obat } \\
\text { melalui intervensi edukasi }\end{array}$ & 25 & 16 & 20 & 8 & 6,3 \\
\hline $\begin{array}{l}\text { Perbaikan penggunaan obat } \\
\text { melalui intervensi manajerial }\end{array}$ & 6 & 5 & 12 & 6 & 2 \\
\hline $\begin{array}{l}\text { Perbaikan penggunaan obat } \\
\text { melalui intervensi regulasi }\end{array}$ & 6 & 5 & 7 & 5 & 1 \\
\hline Penyerahan obat & 12 & 3 & 8 & 8 & 1 \\
\hline $\begin{array}{l}\text { Edukasi dan pemberdayaan } \\
\text { masyarakat }\end{array}$ & 18 & 2 & 3 & 2 & 1,5 \\
\hline Pedoman Pengobatan & 4 & 12 & 8 & 4 & 13,7 \\
\hline $\begin{array}{l}\text { Proses pengambilan keputusan } \\
\text { untuk perubahan ke arah } \\
\text { penggunaan obat yang rasional }\end{array}$ & 5 & 3 & 5 & 2 & 3 \\
\hline $\begin{array}{l}\text { Total sks yang mendukung } \\
\text { PRDU }\end{array}$ & 171 & 83 & 120 & 66 & 36,9 \\
\hline
\end{tabular}

Hasil penelitian ini selaras dengan penelitian Kapol pada tahun 2008 yang melakukan evaluasi konten kurikulum di sebelas perguruan tinggi farmasi di Thailand dengan menggunakan 
kuisioner yang dikembangkan dari standar kompetensi farmasi Thailand. Hasil penelitian menyebutkan bahwa kurikulum pada program bachelor of science in pharmacy (BS Pharm) yang lebih mengarah ke science, lebih banyak konten kurikulum yang berorientasi pada produk. Sedangkan pada program doctor of pharmacy (PhramD) yang lebih mengarah pada pelayanan, lebih banyak konten kurikulum yang berorientasi pada pasien dari standar kompetensi farmasi Thailand.

\section{KELEMAHAN PENELITIAN}

Keterbatasan jumlah data yang diperoleh khususnya data dari wawancara mendalam dan kuesioner menjadikan jumlah data (n) menjadi kecil. Data wawancara mendalam hanya didapatkan dari perguruan tinggi di pulau Jawa, sehingga cenderung menggambarkan pengembangan kurikulum di pulau Jawa, sedangkan data kuesioner semuanya didapatkan dari perguruan tinggi di pulau Jawa dan berstatus sebagai perguruan tinggi farmasi swasta, sehingga hasil lebih cenderung menggambarkan pengembangan kurikulum di perguruan tinggi swasta.

\section{KESIMPULAN}

Jumlah sks total di pendidikan S-1 21 perguruan tinggi farmasi yang diobservasi menunjukkan adanya peningkatan kurang lebih dua kali lipat dengan rentang sks 140 - 158 sks dibandingkan dengan kurikulum inti APTFI yang berjumlah 77 sks. Ini menunjukkan adanya pengembangan muatan lokal dikurikulum masing-masing perguruan tinggi farmasi. Median jumlah sks kurikulum S-1 pada 21 reponden perguruan tinggi farmasi yang paling banyak di perguruan tinggi farmasi swasta dengan 148 sks dibandingkan perguruan tinggi farmasi negeri 146 sks, dan jika dilihat dari tingkatan akreditasi, median jumlah sks diperguruan tinggi farmasi akreditasi $\mathrm{C}$ lebih banyak dengan 154 sks dibandingkan perguruan tinggi akreditasi A dan B masing-masing 145 dan 147 sks. Secara umum Jumlah sks yang mendukung topik inti PRDU course INRUD di tiga perguruan tinggi farmasi dengan akreditasi A lebih banyak dibandingkan dengan perguruan tinggi farmasi akreditasi B, dan jumlah sks pada PTS 4 minat FKK yang mendukung POR sebanyak 120 sks sedangkan minat non FKK berjumlah 66 sks.

\section{UCAPAN TERIMA KASIH}

Ucapan terima kasih kami sampaikan kepada pimpinan perguruan tinggi farmasi yang telah berkenan menjadi responden dalam wawancara dan pengisian kuisioner penelitian. Kami juga menghaturkan terima kasih kepada pengurus APTFI yang telah memberikan dukungan dalam penelitian kami.

\section{DAFTAR PUSTAKA}

APTFI, 2008, Kurikulum Program Pendidikan Apoteker, Asosiasi Perguruan Tinggi Farmasi Indonesia, Yogyakarta, Indonesia

APTFI, 2009, Kurikulum Perguruan Tinggi Farmasi di Indonesia, Asosiasi Perguruan Tinggi Farmasi Indonesia, Jakarta, Indonesia

Ara T., Deva S.A., Bhatia N., 2012. Role of Pharmacist in The Rational Use of Drug, India

BAN-PT, 2012, Pemetaan dan Akreditasi Institusi Farmasi, Badan Akreditasi Nasional Perguruan Tinggi, Jakarta, Indonesia.

INRUD, 2002, Promoting Rational Use of Drug, International Network Rational Use of Drug.

Kapol N., Maitreemit P., Pongcharoensuk P., Amstrong P.E., 2007, Evaluation of Curricula Content Based on Thai Pharmacy Competency Standard, Thailand.

Pemerintah RI, 2009a, Peraturan Pemerintah Nomer 51 tahun 2009 tentang Pekerjaan Kefarmasian, Jakarta, Indonesia.

Pemerintah RI, 2009b, Undang-Undang Kesehatan Nomer 36 tahun 2009, Jakarta, Indonesia

Pemerintah RI, 2013, Permenkes Nomer 71 tahun 2013 tentang Pelayanan Kesehatan pada Jaminan Kesehatan Nasional, Jakarta, Indonesia 
Pemerintah RI, 2014, Permenkes Nomer 35 tahun 2014 tentang Standar Pelayanan Kefarmasian di Apotek, Jakarta, Indonesia

Prawitasari J.E., 1998, Catatan Kuliah Metode Kualitatif untuk Digunakan di Kancah penelitian, Fakultas Psikologi, Universitas Gadjah Mada, Yogyakarta

WHO, 2002, Promoting Rational Use of Medicines : Core Component, World Health Organization, Geneva. 